J. Appl. Glycosci., 56, 223-227 (2009)

(C) 2009 The Japanese Society of Applied Glycoscience

Regular Paper (in Japanese with English Abstract)

\title{
Effect of Sugars on Biofilm Formation by Escherichia coli 0157:H 7
}

(Received January 26, 2009; Accepted March 18, 2009)

\author{
Makoto Yoshida, ${ }^{1, *}$ Shinichi Kawamoto ${ }^{2}$ and Satoshi Kaneko ${ }^{1, * *}$ \\ ${ }^{1}$ Food Biotechnology Division, National Food Research Institute \\ (2-1-12, Kannondai, Tsukuba 305-8642, Japan) \\ ${ }^{2}$ Food Hygiene Laboratory, National Food Research Institute \\ (2-1-12, Kannondai, Tsukuba 305-8642, Japan)
}

\begin{abstract}
The effects of sugars on biofilm formation by Escherichia coli O157:H 7 were investigated by microtiter plate assay. In the cultivation using the medium containing a monosaccharide such as D-glucose, Dgalactose, D-mannose, D-xylose, L-arabinose, L-fucose and L-rhamnose for 7 days, active biofilm formation was observed at 1 day, and then the level of biofilm formation decreased gradually after 3 day. When the bacterium was cultivated in medium containing $0.4,0.04$ or $0.004 \%$ of monosaccharides for 1 day, a low level of biofilm formation was observed in the medium containing $0.4 \%$ D-mannose or L-rhamnose. However, only Dmannose suppressed biofilm formation in the presence of other sugars such as D-glucose.
\end{abstract}

Key words: biofilm, D-mannose, biofilm formation, Escherichia coli 0157:H 7

\section{大腸菌 0157:H 7 のバイオフィルム形成における糖類の影響}

\author{
吉田 誠 ${ }^{1, *}$ ，川本伸一 ${ }^{2}$ ，金子 哲 ${ }^{1, * *}$ \\ ${ }^{1}$ 独立行政法人農業・食品産業技術総合研究機構食品総合研究所食品バイオテクノロジー研究領域 \\ (305-8642 つくば市観音台 2-1-12) \\ 2 独立行政法人農業・食品産業技術総合研究機構食品総合研究所食品安全研究領域 \\ (305-8642 つくば市観音台 2-1-12)
}

食品の安全性は国際的に重大な問題であり，生産から消 費者の口に入るまでの徹底した衛生管理が強く望まれてい るが，細菌による食中毒感染事例は依然として減少してい ない. 近年の研究により，その要因は微生物の生態と大き く関係していることが明らかとなってきた。通常，微生物 はさまざまな物に付着すると多糖を中心とした粘物質を菌 体外に形成し，その中に生息する。その粘物質に包まれた 微生物集合体がすなわちバイオフィルムである。自然界に おいて微生物のほとんどはバイオフィルムとしてなんらか の固体表面上に付着した状態で生息している。バイオフィ ルム中の微生物は浮遊状態に比べ, 抗生物質や薬剤, 乾燥 等に対し，著しく高い抵抗性を示すことが知られてい る $^{1,2)}$. 多糖分解酵素がバイオフィルムの除去に有効である

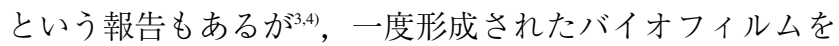
完全に取り除く有効な方法は現時点では開発されていな い.したがって，バイオフィルムは食品の衛生管理におい てきわめて大きな問題となっており，このような背景から その形成をいかに制御するかが衛生管理上の大きな命題と なっている.

大腸菌 O157:H 7 は，1980 年代初頭に見出されたグラム

\footnotetext{
* Present address: Tokyo University of Agricultural and Technology, 3-5-8, Saiwai-cho, Fuchu, Tokyo 183-8509, Japan.

** Corresponding author (Tel. +81-29-838-8063, Fax. +81-29838-7996, E-mail: sakaneko@affrc.go.jp).
}

陰性の腸内病原菌であり5)，きわめて少ない細胞数で食中 毒を引き起こすことが知られている。本菌が生産するべロ 毒素により，出血性大腸炎や溶血性尿毒症症候群，血栓性 血小板減少性紫斑病などが発症し，症状がひどい場合には 死に至ることもある ${ }^{5,6)}$. 大腸菌 $\mathrm{O} 157: \mathrm{H} 7$ は加熱に弱く, $75^{\circ} \mathrm{C}$ で 1 分間の加熱で死滅するにも関わらず，現在も食 中毒の感染例が後を絶たない。既往の研究により，本菌は ステンレススチールなどの非生物表面上にバイオフィルム を形成できることが知られている7,8).このことは，本菌が 水道管や流し表面上にバイオフィルムを形成する可能性が あり，これら非生物表面が大腸菌 O157:H 7 の媒体となり うる可能性を示唆している。

大腸菌 O157:H 7 のバイオフィルム形成の結果として引 き起こされる食品污染を防止するためには，本菌のバイオ フィルム形成機構に関する生理学的理解が不可欠である. これまでに温度, $\mathrm{pH}$, 振とうなどの環境要因がバイオ フィルム形成に与える影響については報告されてきてい る ${ }^{7,910)}$. しかしながら，バイオフィルムの主成分が多糖類 であるにもかかわらず，糖類の影響についてはほとんど知 られていない。そこで本研究では, 種々の糖類が大腸菌 O157:H 7 のバイオフィルム形成に与える影響について調 査したので報告する。

実験の第一段階として，バイオフィルム形成条件の最適 化を行った，大腸菌 O157:H 7 CR-3 株, MN-28 株，MY- 
29 株, DT-66 株を前培養し, 得られた菌体を生理食塩水 で洗浄した後，ポリプロピレン製 96 穴マイクロプレート 中の培地に接種した。培地として $0.04 \%$ の D-グルコース を含む最少培地およびダルベッコ改変イーグル培地を用い た。接種した菌を 24 時間静置培養した後, 蒸留水でウェ ル内を良く洗浄し, ウェル内に付着した菌体をクリスタル バイオレットで可視化した。 実験の結果，DT-66が最も多 量のバイオフィルムを形成し, その最適培養条件は, 最少 培地 ( $\mathrm{pH} 4), 37^{\circ} \mathrm{C}$ であった。 よって, 以後の実験には本 条件を用いることとした。

各種の糖類を含む培地における菌体成長およびバイオ フィルム形成の経日変化を調査した，前述したものと同様 の条件下で, DT-66 株を 0.04\%の D-グルコース, D-ガラ クトース, $\mathrm{D}-$ マンノース, $\mathrm{D}$-キシロース, L-アラビノー ス, L-フコース, L-ラムノースをそれぞれ単一の炭素源と する最少培地で培養し， $1,3,7$ 日目の菌体量およびバイ オフィルム形成量を測定した。その結果, 糖の種類に関わ らず，菌体量はすべての培地で培養 1 日目におおむね最大 值に達し, その浮遊細胞密度は培養後期まで維持された (Fig. 1 (A)). L-ラムノースを含む培地における菌体生長量 は, 他の培地と比較して低かった。一方, バイオフィルム の量も培養 1 日目に最大值まで達したが, その後, 徐々に 減少することが明らかとなった (Fig. 1 (B)). 緑膿菌Pseudomonas aeruginosa を対象とした既往の研究において, 飢 餓状態がバイオフィルムからの細胞の遊離を引き起こすこ とが報告されている ${ }^{11}$. それゆえ, 本研究で観察された培
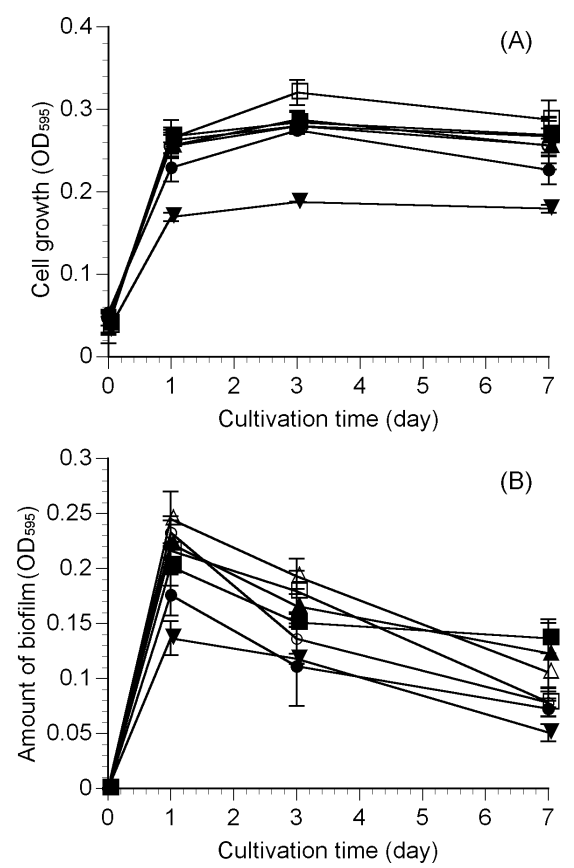

Fig. 1. Time course of bacterial growth (A) and biofilm formation (B).

DT 66 was cultivated in minimal medium containing $0.04 \%$ Dglucose $(\bullet)$, D-galactose $(\bigcirc)$, D-mannose $(\mathbf{\Delta})$, D-xylose $(\triangle)$, Larabinose $(\boldsymbol{\square})$, L-fucose $(\square)$ or L-rhamnose $(\boldsymbol{\nabla})$ as the sole source of carbon. After culture for 1, 3 or 7 days, the bacterial cell density and amount of biofilm were determined. Each error bar shows the standard error in triplicate tests for each sample.
養後期のバイオフィルム量の減少は, 培地中の栄養素の不 足による飢餓状態が原因であると考えられる。

糖濃度がバイオフィルム形成に与える影響を調べるため に，単一の炭素源として上記の糖類をそれぞれ 0.4, 0.04 , $0.004 \%$ 含む最少培地で培養し，24 時間後のバイオフィル ム形成量を測定した。その結果，0.4 および $0.04 \%$ の糖類 を含む培地で最もバイオフィルム量が多かった (Table 1). しかしながら，興味深いことに，D-マンノースおよび L-ラ ムノースを $0.4 \%$ 含む培地においては，きわめて少量のバ イオフィルムが確認された。同条件下において浮遊菌体密 度に大きな影響は観察されなかったことから，これらの糖 類が菌体の生育に悪影響を及ほしたとは考えにくく，した がって，これらの糖類が直接的にバイオフィルムの形成を 阻害した可能性が考えられた。

上記の実験により，D-マンノースおよび L-ラムノースが バイオフィルム形成を阻害する可能性が示唆されたことか ら，それらの糖類とバイオフィルム形成の関連をさらに詳 しく調査するため，以下の実験を行った。菌体を D-グル コース，D-ガラクトース， D-キシロース，L-アラビノー ス，L-フコースを $0.4 \%$ 含む最少培地に $0.4 \%$ の D-マン ノースおよび $\mathrm{L}-$ ラムノースを添加し，培養 24 時間後のバ イオフィルム形成量を測定した (Table 2). その結果，Lラムノースの添加, 無添加両培地においてバイオフィルム の量に差異は観察されなかった。このことから，L-ラム ノースはバイオフィルムを直接的に阻害するものではない と考えられた. Fig. 1でみられたように，L-ラムノース含 有培地における菌体生長量は, 他の培地と比較して低かっ た。このことは, 大腸菌 O157:H 7 における L-ラムノース

Table 1. Effect of sugar concentrations on biofilm formation.

\begin{tabular}{lccc}
\hline & \multicolumn{3}{c}{ Amount of biofilm $\left(\mathrm{OD}_{595}\right)$} \\
\cline { 2 - 4 } & \multicolumn{3}{c}{ Sugar concentration $(\%)$} \\
\hline D-Glucose & 0.4 & 0.04 & 0.004 \\
D-Galactose & $0.16 \pm 0.004$ & $0.18 \pm 0.009$ & $0.12 \pm 0.008$ \\
D-Mannose & $0.07 \pm 0.024$ & $0.23 \pm 0.012$ & $0.13 \pm 0.017$ \\
D-Xylose & $0.21 \pm 0.006$ & $0.22 \pm 0.037$ & $0.13 \pm 0.007$ \\
L-Arabinose & $0.20 \pm 0.008$ & $0.21 \pm 0.032$ & $0.15 \pm 0.015$ \\
L-Fucose & $0.23 \pm 0.011$ & $0.23 \pm 0.013$ & $0.17 \pm 0.001$ \\
L-Rhamnose & $0.07 \pm 0.016$ & $0.16 \pm 0.027$ & $0.13 \pm 0.027$ \\
\hline
\end{tabular}

Each experiment was carried out in triplicate.

Table 2. Effect of D-mannose or L-rhamnose on biofilm formation.

\begin{tabular}{lccc}
\hline & \multicolumn{3}{c}{ Amount of biofilm $\left(\mathrm{OD}_{595}\right)$} \\
\cline { 2 - 4 } Carbon source & No additive & $\begin{array}{c}\text { D-Mannose } \\
\text { added }^{\mathrm{b}}\end{array}$ & $\begin{array}{c}\text { L-Rhamnose } \\
\text { added }^{\mathrm{b}}\end{array}$ \\
\cline { 2 - 4 } & $0.15 \pm 0.004$ & $0.11 \pm 0.005$ & $0.14 \pm 0.012$ \\
D-Glucose $^{\mathrm{a}}$ & $0.16 \pm 0.005$ & $0.12 \pm 0.004$ & $0.14 \pm 0.012$ \\
D-Galactose $^{\mathrm{a}}$ & $0.21 \pm 0.006$ & $0.12 \pm 0.012$ & $0.20 \pm 0.020$ \\
D-Xylose $^{\mathrm{a}}$ & $0.20 \pm 0.008$ & $0.12 \pm 0.005$ & $0.20 \pm 0.024$ \\
L-Arabinose $^{\mathrm{a}}$ & $0.23 \pm 0.016$ & $0.13 \pm 0.011$ & $0.22 \pm 0.024$ \\
L-Fucose $^{\mathrm{a}}$ & &
\end{tabular}

${ }^{\mathrm{a}} 0.4 \%$ (w/v) sugar was used. ${ }^{\mathrm{b}} 0.4 \%$ (w/v) D-mannose or $\mathrm{L}$ rhamnose was added. Each experiment was carried out in triplicate. 
の代謝様式が他の糖類と異なることを示唆している。した がって，その代謝様式の違いが，Table 1 で観察された $0.4 \%$ L-ラムノース含有培地に打ける低レベルのバイオ フィルム形成に反映されたのではないかと予想される。

一方，D-マンノースを添加した培地においては，すべて の培地においてバイオフィルム形成の低下が認められた. 同条件に抒いて菌体成長には変化が観察されなかったこと から，D-マンノースは大腸菌 O157:H 7 のバイオフィルム 形成を直接的に阻害することが示唆された。さらに，D-マ ンノースによるバイオフィルム形成の抑制効果は，ステン レススチール表面においても観察された。よって，この抑 制効果は固体の性質や表面構造に依存しないと考えられ る. 大腸菌は 1 型繊毛先端にD-マンノース結合性タンパ ク質 (FimH) を有することが明らかにされている12. FimH は哺乳細胞表面糖鎖のマンノース残基に吸着し，宿主への 感染を媒介するタンパク質であり ${ }^{13)}$ ，D-マンノースの添加 によりその機能が阻害される ${ }^{14}$. また，バイオフィルム形 成に 1 型繊毛が関与することが示唆されており，その先端 に存在する FimH の関与が議論されている ${ }^{15}$. しかしなが ら，多くの大腸菌 O157:H 7 においては FimH の発現は確 認されているものの 1 型繊毛が認められないという報告が あり ${ }^{10)} ， 1$ 型瀻毛と異なる部位に FimH が局在し，独立に 機能していることを示唆している．また，D-マンノースが 大腸菌 O157:H 7 の上皮細胞への付着を阻害するという報 告もなされており ${ }^{17)}$, FimH の細胞接着への関与は確実で ある. 本研究で見出した，D-マンノースがバイオフィルム 形成を抑制する現象は，FimH がD-マンノースにコーティ ングされることにより，固体表面への大腸菌 O157:H 7 の 接着が減少したためと考えられる。オリゴ糖を使用した実

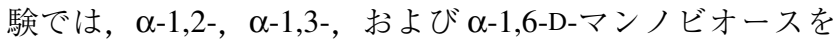
用いた場合にD-マンノースと同様の結果が得られたが, 及-1,4-D-マンノビオースにはその機能がなかったことから も, FimH のコーティングによる接着性の低下により形成 されるバイオフィルムの量が減少したというメカニズムが 示唆されるが，その詳細を解明するには，さらなる研究が 必要である。

近年，D-マンノースがマクロファージの活性を高める機 能 ${ }^{18}$ や抗炎症作用を有する ${ }^{19)}$ こど明らかとなり，医療分 野への応用が期待されている。 また，食品加工分野でも， D-マンノースが家畜の腸内に打いて，病原菌の繁殖を抑え る効果が知られて抢り ${ }^{20}$, 䳕卵のサルモネラ菌対策, 子豚 の大腸菌感染の予防を目的として, D-マンノース含有飼料 がすでに実用化され，商業的に流通している，本研究に拀 いて見いだされた，D-マンノースが他の糖類の存在下にお いても大腸菌 O157:H 7 のバイオフィルム形成を阻害する という現象は，我々が知る限り世界で初めての報告であ る。したがって本研究は，D-マンノースの食品衛生分野へ の応用の可能性を大きく広げるものである.

\section{実 験 方 法}

\section{1. 実 験 材 料}

本研究では，大腸菌 CR-3 株，MN-28 株，MY-29 株, DT-66 株（すべて牛の穓由来のもの）を用いた占，最少培 地として，0.7\% (w/v) リン酸水素二カリウム， $0.3 \%(\mathrm{w} /$ v) リン酸二水素カリウム， $0.1 \%(\mathrm{w} / \mathrm{v})$ 硫酸アンモニウ 厶, $0.01 \%(\mathrm{w} / \mathrm{v})$ 硫酸マグネシウム・7 水和物， $0.0001 \%$ $(\mathrm{w} / \mathrm{v})$ 酵母抽出物㧍よび適当量の糖類を含む培地を用い た。ダルベッコ改変イーグル培地は，ナカライテスク侏製 のものを用いた。

\section{2. バイオフィルム量の測定}

本研究では，96穴マイクロプレートを用いて，既往の 方法 ${ }^{22} に$ に従いバイオフィルム量を測定した。マイクロプ レートウェル内の培地を除去した後, 滅菌超純水により 5 回洗浄した。プレートを風乾した後，バイオフィルム中 の菌体を $0.5 \%(\mathrm{w} / \mathrm{v})$ クリスタルバイオレットで 10 分間 染色した。その後, 滅菌超純水により 5 回洗浄し, 残留色 素を $200 \mu \mathrm{L}$ の 95\% (v/v) エタノールで溶出した。これを 良く混合した後， $\mathrm{OD}_{595}$ を測定した。

\section{3. 大腸菌 O157:H 7 の培養}

1) 前培養

大腸菌 $\mathrm{O} 157: \mathrm{H} 7$ を $10 \mathrm{~mL}$ の $\mathrm{LB}$ 培地で $37^{\circ} \mathrm{C}, 14$ 時間培 養した後，遠心分離 $(2000 \times g ， 1$ 分間) した。得られた 菌体を $0.85 \%$ の生理食塩水に懸濁し，ポリプロピレン製 96 穴マイクロプレート中の培地に各実験に適切な $\mathrm{OD}_{599}$ の 值となるように接種した。

2 ) バイオフィルム形成のための培養

バイオフィルム形成条件の最適化を行うため, 大腸菌 O157:H 7 の 4 株を用いて実験を行った。前培養液を 0.04\% (w/v) D-グルコース含有最少培地抒よびダルベッコ 改変イーグル培地に $\mathrm{OD}_{595}$ が 0.05 となるように接種した。 各培養は $200 \mu \mathrm{L}$ の系で行った。各培地は $\mathrm{pH}$ 4-7 に調整 し，培養容器としてポリスチレン製の96穴マイクロプ レートを用いた $37^{\circ} \mathrm{C} ， 24$ 時間静置した後，上記の方法 によりバイオフィルム中の菌体を可視化した。

種々の糖類を含む培地における菌体の生育およびバイオ フィルム形成の経日変化を，次のようにして調査した。前 培養液を $0.04 \%(\mathrm{w} / \mathrm{v}) \mathrm{D}-$ グルコース，D-ガラクトース， Dマンノース， D-キシロース， L-アラビノース， L-フコー ス，L-ラムノースをそれぞれ単一の炭素源とする最少培地 $(\mathrm{pH} 4)$ に $\mathrm{OD}_{995}$ が 0.05 となるように接種し， $37^{\circ} \mathrm{C}$ で 7 日 間静置培養した。各培養は $200 \mu \mathrm{L}$ の系で行った。培養 1 , 3, 7 日の培養液の $\mathrm{OD}_{595}$ を測定し, 菌体量とした。さら に, 各培養日数のバイオフィルムの量を上記の方法により 測定した。

バイオフィルム形成に対する糖濃度の影響を調査するた め，以下のと扔り実験を行った。それぞれ $0.4 \%(\mathrm{w} / \mathrm{v})$, 0.04\% (w/v)，0.004\% (w/v) の D-グルコース，D-ガラク 
トース，D-マンノース，D-キシロース，L-アラビノース， L-フコース，L-ラムノースを単一の炭素源とする最少培地 ( $\mathrm{pH} 4)$ を調製し，そこに前培養液を $\mathrm{OD}_{595}$ が 0.2 となるよ うに接種し， $37^{\circ} \mathrm{C} て ゙ 24$ 時間静置培養した。各培養は 200 $\mu \mathrm{L}$ の系で行った。その培養液の $\mathrm{OD}_{595}$ を測定し, 菌体量 とし,さらにバイオフィルムの量を上記の方法により測定 した.

D-マンノースおよびL-ラムノースによるバイオフィルム 形成の抑制効果を，以下のと抢り調査した。それぞれ $0.4 \%(\mathrm{w} / \mathrm{v})$ の D-グルコース, D-ガラクトース, D-キシ ロース，L-アラビノース，L-フコースを単一の炭素源とす る最少培地 $(\mathrm{pH} 4)$ を調製し，そこに最終濃度 $0.4 \%(\mathrm{w} / \mathrm{v})$ となるようにD-マンノースおよび $\mathrm{L}$-ラムノースを添加し

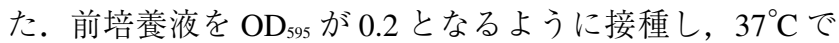
24 時間静置培養した. 各培養は $200 \mu \mathrm{L}$ の系で行った. 静 置後の培養液の $\mathrm{OD}_{595}$ を測定し, 菌体量とし, さらにバイ オフィルムの量を上記の方法により測定した。糖濃度の影 響を考慮し，D-グルコースをコントロールとして同様の実 験を行ったが，糖濃度による影響は認められなかった。

本研究は，農林水産省委託プロジェクト「食品・農産物 の表示の信頼性確保と機能性解析のための基盤技術の開 発」の予算により実施されたものである.

\section{文献}

1 ) B.D. Hoyle and J.W. Costerton: Bacterial resistance to antibiotics: the role of biofilms. Prog. Drug. Res., 37, 91-105 (1991).

2 ) P.S. Stewart and J.W. Costerton: Antibiotic resistance of bacteria in biofilms. Lancet, 358, 135-138 (2001).

3 ) Y. Itoh, X. Wang, B.J. Hinnebusch, J.F. Preston III and T. Romeo: Depolymerization of $\beta-1,6-N$-acetyl-D-glucosamine disrupts the integrity of diverse bacterial biofilms. J. Bacteriol., 187, 382-387 (2005)

4 ) T.K. Lu and J.J. Collins: Dispersing biofilms with engineered enzymatic bacteriophage. Proc. Natl. Acad. Sci. USA, 104, 11197-11202 (2007)

5 ) L.W. Riley, R.S. Remis, S.D. Helgerson, H.B. McGee, J.G. Wells, B.R. Davis, R.J. Hebert, E.S. Olcott, L.M. Johnson, N. T. Hargrett, P.A. Blake and M.L. Cohen: Hemorrhagic colitis associated with a rare Escherichia coli serotype. N. Engl. J. Med., 308, 681-685 (1983).

6 ) G. Reiss, P. Kunz, D. Koin and E.B. Keeffe: Escherichia coli O157:H 7 infection in nursing homes: review of literature and report of recent outbreak. J. Am. Geriatr. Soc., 54, 680-684 (2006).

7 ) R. Dewanti and A.C.L. Wong: Influence of culture conditions on biofilm formation by Escherichia coli O157:H 7. Int. J. Food Microbiol., 26, 147-164 (1995).

8 ) J.H. Ryu, H. Kim, J.F. Frank and L.R. Beuchat: Attachment and biofilm formation on stainless steel by Escherichia coli O157:H 7 as affected by curli production. Lett. Appl. Microbiol., 39, 359-362 (2004).

9 ) M.E. Coleman, M.L. Tamplin, J.G. Phillips and B.S. Marmer: Influence of agitation, inoculum density, $\mathrm{pH}$, and strain on the growth parameters of Escherichia coli O157:H 7 - relevance to risk assessment. Int. J. Food. Microbiol., 83, 147-160 (2003).

10) J.H. Ryu and L.R. Beuchat: Factors affecting production of extracellular carbohydrate complexes by Escherichia coli $\mathrm{O} 157: \mathrm{H}$ 7. Int. J. Food Microbiol., 95, 189-204 (2004).

11) S.M. Hunt, E.M. Werner, B. Huang, M.A. Hamilton and P.S.
Stewart: Hypothesis for the role of nutrient starvation in biofilm detachment. Appl. Environ. Microbiol., 70, 7418-7425 (2004).

12) K.A. Krogfelt, H. Bergmans and P. Klemm: Direct evidence that the FimH protein is the mannose-specific adhesin of $E s$ cherichia coli type 1 fimbriae. Infect. Immun., 58, 1995-1998 (1990).

13) G. Zhou, W.J. Mo, P. Sebbel, G. Min, T.A. Neubert, R. Glockshuber, X.R. Wu, T.T. Sun and X.P. Kong: Uroplakin Ia is the urothelial receptor for uropathogenic Escherichia coli: evidence from in vitro FimH binding. J. Cell Sci., 114, 4095-4103 (2001).

14) C.S. Hung, J. Bouckaert, D. Hung, J. Pinkner, C. Widberg, A. DeFusco, C.G. Auguste, R. Strouse, S. Langermann, G. Waksman and S.J. Hultgren: Structural basis of tropism of Escherichia coli to the bladder during urinary tract infection. Mol. Microbiol., 44, 903-915 (2002).

15) L.A. Pratt and R. Kolter: Genetic analysis of Escherichia coli biofilm formation: roles of flagella, motility, chemotaxis and type I pili. Mol. Microbiol., 30, 285-293 (1998).

16) M. Enami, N. Nakasone, Y. Honma, S. Kakinohana, J. Kudaka and M. Iwanaga: Expression of type I pili is abolished in verotoxin-producing Escherichia coli O157. FEMS Microbiol. Lett., 179, 467-472 (1999).

17) D.K. Winsor Jr., S. Ashkenazi, R. Chiovetti and T.G. Cleary: Adherence of enterohemorrhagic Escherichia coli strains to a human colonic epithelial cell line (T 84). Infect. Immun., 60, 1613-1617 (1992)

18) I. Takata, K. Chida, M.R. Gordon, Q.N. Myrvik, M.J. Ricardo and L.S. Kucera: L-Fucose, D-mannose, L-galactose, and their BSA conjugates stimulate macrophage migration. J. Leukoc. Biol., 41, 248-256 (1987)

19) J. Kössi, J. Peltonen, T. Ekfors, J. Niinikoski and M. Laato: Effects of hexose sugars: glucose, fructose, galactose and mannose on wound healing in the rat. Eur. Surg. Res., 31, 74-82 (1999).

20) B.A. Oyfo, J.R. DeLoach, D.E. Corrier, J.O. Norman, R.L. Ziprin and H.H. Mollenhauer: Prevention of Salmonella typhimurium colonization of broilers with D-mannose. Poult. Sci., 68, 1357-1360 (1989).

21) Y. Inatsu, M.L. Bari, S. Kawasaki, K. Isshiki and S. Kawamoto: Efficacy of acidified sodium chlorite treatments in reducing Escherichia coli O157:H 7 on Chinese cabbage. J. Food Prot., 68, 251-255 (2005).

22) N. Wakimoto, J. Nishi, J. Sheikh, J.P. Nataro, J. Sarantuya, M. Iwashita, K. Manago, K. Tokuda, M. Yoshinaga and Y. Kawano: Quantitative biofilm assay using a microtiter plate to screen for enteroaggregative Escherichia coli. Am. J. Trop. Med. Hyg., 71, 687-690 (2004). 


\section{大腸菌 O157:H 7 の}

\section{バイオフィルム形成に対する糖類の影響}

吉田 誠'，川本伸一 ${ }^{2}$ ，金子 哲 ${ }^{1}$

1 農業・食品産業技術総合研究機構食品総合研究所

食品バイオテクノロジー研究領域

(305-8642 つくば市観音台 2-1-12)

2 農業・食品産業技術総合研究機構食品総合研究所

食品安全研究領域

(305-8642 つくば市観音台 2-1-12)

大腸菌 O157:H 7 を D-グルコース，D-ガラクトース，Dマンノース，D-キシロース， L-アラビノース，L-ラムノー ス，L-フコースをそれぞれ単一の炭素源として $0.04 \%$ 含む 培地で 7 日間培養し，菌体生長量および形成されたバイオ フィルムの量を測定した。その結果，すべての培地におい て, 培養 1 日目で菌体量が最大に達した (Fig. 1 (A)). 同 様に，バイオフィルムの量も培養 1 日目に最大值を示し, その後, 減少した (Fig. 1 (B)). 糖類の濃度がバイオフィ ルム形成に与える影響を調べるため, 上記の糖類を単一の 炭素源として $0.4 ， 0.04 ， 0.004 \%$ 含む培地をそれぞれ調製 し，1 日間培養した。その結果， $0.4 \%$ の D-マンノース挰 よび L-ラムノースを含む培地に抒いて, 本菌のバイオ フィルム形成能の低下が観察された (Table 1). さらに, D-グルコース， D-ガラクトース， D-キシロース， L-アラビ ノース，L-フコースを含む培地にD-マンノースおよび $\mathrm{L}-$ ラムノースをそれぞれ添加し, 大腸菌 O157:H 7 を培養し た結果, D-マンノースを添加した培地のみバイオフィルム 形成の低下が観察された (Table 2). D-マンノースの添加 培地と無添加培地において, 菌体生長量に変化は観察され なかったことから，D-マンノースは大腸菌 O157:H 7 のバ イオフィルム形成を直接的に阻害すると考えられた。 